\title{
The Effects Of Channels Of Distribution On Nigerian Product Sales
}

\author{
Mrs. R.N. Obaji, University Of Lagos, Nigeria
}

\begin{abstract}
This study investigated the effects of channels of distribution in a selected Nigerian manufacturing company as it affects sales of its product. The quantitative research method was the instrument used to collect data for the study. A total of 300 copies of the questionnaires were distributed to sampled consumers, distributors and marketing staff of the company, out of which 200 copies was retrieved back. The data was analyzed using the Statistical Package for Social Science (SPSS) version 15 and the t-Test statistical tool was employed to test the significance between the observed variables and the underlying construct. The findings revealed that the involvement of channels of distribution affects sales of product and that consumers prefer to buy from intermediaries than from producer channels. Based on the underlying assumption, the following were recommended for the study; that the channel members should influence several key decisions such as customer service, delivery, and maintain inventory control and the company should give adequate promotional support to the intermediaries, improve on delivery terms and also evaluate channel members regularly.
\end{abstract}

Keywords: Channels of Distribution; channel members

\section{INTRODUCTION}

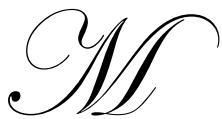

arketing Channel decisions are among the most important decisions that management faces today. Indeed, if one look at the major strategy of the marketing mix - product, price, promotion and distribution, the greatest potential for achieving a competitive advantage now lies in distribution. Distribution still offers a new frontier for competing successfully especially if the emphasis is placed on the design and management of superior marketing channel systems to provide excellent customer services. Yet designing optimal marketing channel system to boost sales, formulating innovative distribution strategies and managing channels system effectively is no simple task.

Today, companies are faced with choice of distribution path or strategy that will make product readily available to potential customers. Achumba (2000). Also the need for other institutions or intermediaries in the delivery of goods is sometimes questioned, particularly since the profits they make are viewed as adding to the cost of the product. The concept of distribution refers to where and how product and services are to be offered for sale, all essential mechanism and logistical supports for the transfer of goods and services as well as ownership of goods and services to the customers. Stern et al (2006).

\section{OBJECTIVES OF THE STUDY}

The objectives of this study are:

(i) To examine the effectiveness of channels of distribution used by manufacturing companies.

(ii) To determine whether the involvement of distribution channels used by manufacturing companies improve sales of their products. 


\section{RESEARCH QUESTIONS}

(i) Does the involvement of channel members by these manufacturing companies improve sales of their products?

(ii) How effective and efficient are the distribution channels used by the manufacturing companies to distribute their product?

\section{The following Research Hypotheses was proposed}

$\mathbf{H}_{1}$ : That involvement of distribution channels affect sales of products.

$\mathbf{H}_{2}$ : $\quad$ Consumers prefers to buy from company's direct channel than buying from intermediaries

\section{CHANNEL LEVELS}

All products whether they be consumer goods, industrial goods or services require a channel of distribution. Mallen (1996) stated that industrial channels tend to be shorter than consumer channels because of the small number of ultimate customers, the greater geographic concentration of industrial customers, and greater complexity of the products which require close producer-customer liaison. Kotler and Keller (2006) presented three levels in consumer channels strategy. According to him a one - level channel contains one selling intermediary such as a retailer. He found that the growth in retailer size has meant that it becomes economic for producers to supply retailers directly rather than through wholesalers, hence consumers now have the convenience of viewing and testing the product at the retail outlet. A two - level channel contains two intermediaries, a wholesaler and a retailer. According to him channels like this tend to occur where there are influxes of small retailers with limited order quantities; wholesalers can buy in bulk from producers and sell smaller quantities to numerous retailers. He maintained that a three- level channel contains three- intermediaries that is sometimes used by companies entering into foreign markets and may delegate the task of selling the product to an agent (who does not take title to the goods). Moreover the agent contacts the wholesalers who supply's the retailers till it gets to the ultimate consumer.

Black (2002) described the service channels as distribution channels of short services using either direct channel or an agent, and posits that since stocks are not held, the role of the wholesalers, retailers or industrial distributors does not apply. Examples of service provider to consumers or industrial customers include healthcare, office cleaning, accountancy, marketing research and law. Agents are used when the service provider is geographically distant from customers and where it is not economical for the provider to establish their own local sales team. Examples include insurance, travel, secretarial and theatrical agents.

\section{Consumer marketing channels}

0-level

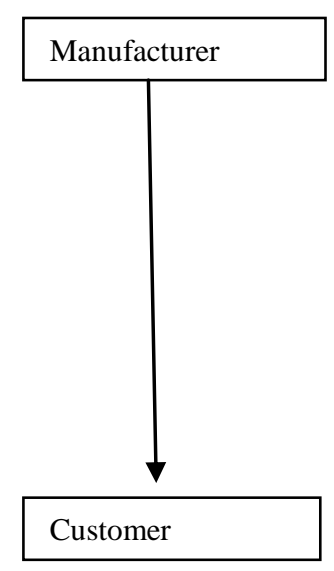

1-level

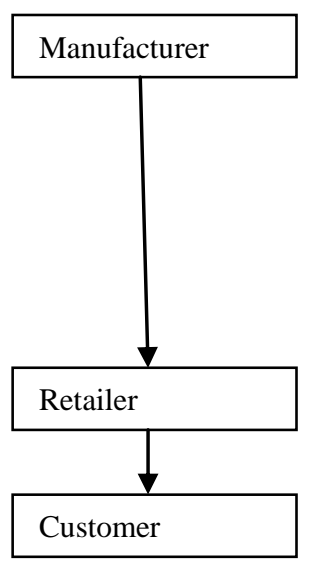

2-level

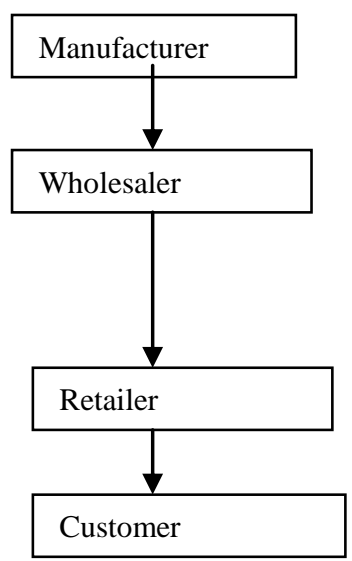

3-level

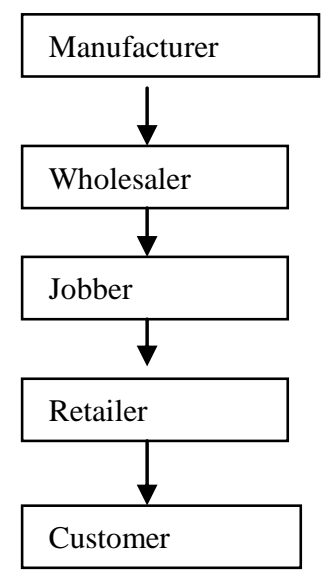

Source: Kotler, Philip and Keller, Kevin (2006). Marketing Management, Pearson Educational Prentice Hall NY 
Industrial marketing channels

0-level

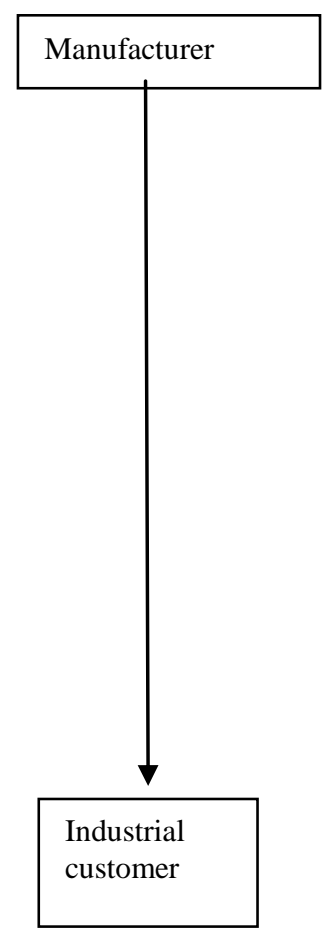

1-level

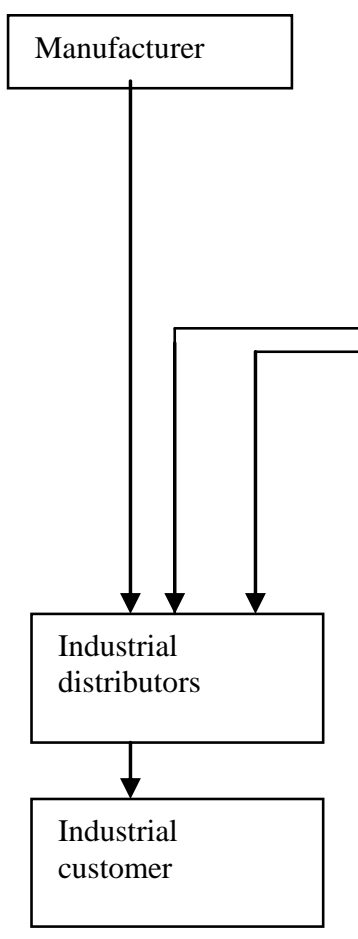

2-level

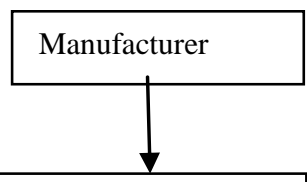

Manufacturer's representatives 3-level

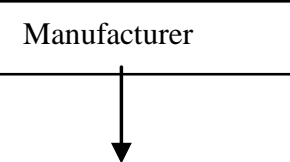

Manufacturer's sales branch

Source: Kotler, Philip and Keller, Kevin (2006). Marketing Management, Pearson Educational Prentice Hall NY

\section{Channels of Distribution}

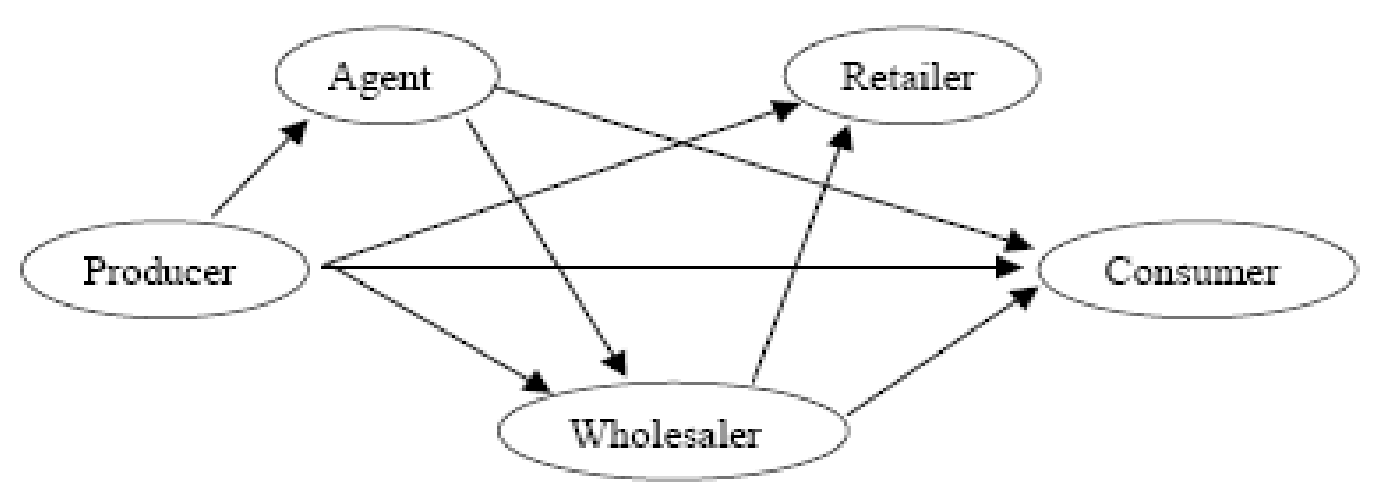

Source: National Institute of Open Schooling (NIOS); Channels of Distribution; Lesson 20 New Delhi, India. (2007) www.nos.org

\section{RESEARCH METHODOLOGY}

The data collected for this research work came through interview, observation and completed questionnaires by respondents. The adoption of questionnaires as source of primary data was to obtain the primary data needed while the follow-up interview was to sensitize the respondents view on some of the issues raised in the questionnaires. 
The importance of this method cannot be overemphasized considering some of the shortcomings of using questionnaires especially in this kind of research where adequate responses cannot be guaranteed. Secondary data was collected through publications, journals etc.

The population of this study comprises of distributors, wholesalers, retailers and consumers situated in Lagos. The sample size of this study was 300 respondents while a stratified sampling technique was used to ensure that every member of the group has equal chance of being represented in the sample.

In order to have a more effective sampling of the various groups and cadres, the following numbers were sampled from each group:

1. Channel Distributors 100

2. Consumers 180

3. Distribution and Marketing staff of manufacturing companies 20

The sample was randomly selected to represent the totality of the targeted population and questionnaire was administered.

\section{PRESENTATION AND ANALYSIS OF DATA}

The sample size of the study is three hundred (300) comprising of one hundred and eighty consumers, one hundred distributors and twenty company staffs. However, out of the three hundred questionnaires that were administered to the three types of respondents used in the study, the researcher was able to retrieve eighty (80) from the channel distributors, one hundred (100) from the consumers and twenty (20) from company staffs.

The two hundred questionnaires were interpreted and analysed to test for the hypotheses formulated for the study.

DESCRIPTIVE STATISTICS OF THE EFFECTS OF CHANNELS OF DISTRIBUTION ON THE SALES OF A PRODUCT

\begin{tabular}{|c|c|c|c|c|}
\hline & Mean & Std & Skewness & Kurtosis \\
\cline { 2 - 5 } & Statistic & Statistic & Statistic & 2.162 \\
\hline A1 & 4.20 & 1.082 & -1.629 & -1.511 \\
\hline A2 & 2.11 & .827 & -.209 & -1.364 \\
\hline A3 & 2.05 & 1.424 & -.368 & -.486 \\
\hline A5 & 1.42 & 1.156 & .499 & -.599 \\
\hline A6 & 1.29 & .924 & -1.679 & 1.274 \\
\hline A7 & 3.54 & 1.096 & .396 & -1.108 \\
\hline A8 & 2.80 & 1.198 & -.481 & -1.388 \\
\hline A10 & 3.39 & 1.569 & 1.255 & -.069 \\
\hline A11 & 1.95 & 1.486 & 1.050 & 1.343 \\
\hline A12 & 2.60 & .910 & .286 & -1.490 \\
\hline A13 & 3.17 & 1.371 & -.077 & -1.704 \\
\hline A14 & 3.45 & 1.321 & .434 & -.554 \\
\hline A16 & 2.26 & .924 & 1.108 & -.317 \\
\hline A17 & 1.75 & 1.097 & 1.102 & .166 \\
\hline A18 & 2.31 & 1.269 & -.055 & -.255 \\
\hline A19 & 2.13 & .603 & .316 & .960 \\
\hline A20 & 1.13 & .487 & -.545 & -.1 .230 \\
\hline A21 & 3.55 & 1.492 & .000 & 1.144 \\
\hline F & 2.00 & .503 & .119 & 1.871 \\
\hline
\end{tabular}

Source: Field work (2010) 
From the above table, it can be seen that based on the descriptive statistics, the mean value of all the variables of (A1-A21) shows that the involvement of distribution channels has positive effects on the sales of a product. This is based on the analysis of the difference in the sales of product between producer and other channels of distribution. It also shows that variable (A21) has the highest extent because the company engages in multichannel strategy.

\section{Analysis of T-test Result}

\section{Hypothesis 1}

$\mathbf{H}_{\mathbf{i}}$ : $\quad$ There were significant difference in the Sales of Products between Producer and Other Distributors i.e. That involvement of distribution channel affect sales of product

\begin{tabular}{|l|c|c|c|c|c|c|c|}
\hline \multicolumn{1}{|c|}{ Sales of products } & $\mathbf{N}$ & Mean & Std. Dev. & Crit-t & Cal-t. & DF & P \\
\hline Producer & 36 & 28.5833 & 03.9015 & \multirow{2}{*}{2.00} & 2.182 & 98 & .032 \\
Other distributors & 64 & 30.6719 & 04.9379 & & & \\
\hline
\end{tabular}

Source: Field work (2010)

The result of the t-test revealed that there were significant difference in the sales of product between producer and other distributors (Crit-t $=2.00$, Cal.t $=2.182, \mathrm{df}=98, \mathrm{P}<.05$ level of significance).

The null hypothesis is therefore rejected.

$\mathrm{H}_{\mathrm{i}}$ is accepted

From this result it could be said that the involvement of distribution channels affects sales of the product.

\section{Hypothesis 2}

H2: Consumers prefer to buy from intermediaries

\begin{tabular}{|l|c|c|c|c|c|c|c|}
\hline \multicolumn{1}{|c|}{ Sales of products } & $\mathbf{N}$ & Mean & Std. Dev. & Crit-t & Cal-t. & DF & P \\
\hline Producer & 16 & 18.1250 & 02.3058 & \multirow{2}{*}{2.00} & 2.856 & 78 & .005 \\
Other distributors & 64 & 15.4531 & 03.5498 & & & & \\
\hline
\end{tabular}

Source: Field work (2010)

The above table showed that there were significant difference in the sales of product to consumers between producer and other distributors $($ Crit- $\mathrm{t}=2.00$, Cal.t $=2.856 \mathrm{df}=78, \mathrm{P}<.05$ level of significance)

The null hypothesis is therefore rejected.

$\mathrm{H}_{\mathrm{i}}$ is accepted

From this result, it could be concluded that majority of the consumers prefer to buy from intermediaries than buying from the producers directly.

\section{SUMMARY OF FINDINGS}

Findings of this study revealed that there are host of factors that influence the structure and overall strategy of distribution channels. Data collected and analyzed showed that there were significant difference in the sales of 
product between the producer and other distributors.

This shows that involvement of distribution channel affect sales of product. The analyses equally reveal that people do not prefer to buy the product from company's direct channel but buys steadily from intermediaries, buttressing the relevance of channels of distribution adopted by the company.

\section{CONCLUSION FROM FINDINGS}

Many manufacturing companies have long looked upon distribution channels as "customers" and rarely bothered to look beyond .Yet the primary purpose of the distribution channel is to satisfy customer/end-user needs, and intermediaries are conduits to effect this goal.

The profit margin derived by channel members in distributing the company's products is very low. This sometimes makes them reduce the level of inventory carried and switch for other competitive products. Channel members complained of transportation problems which distorts timely delivery of the product to their warehouse and stores, and invariably led to additional cost, damage and sometimes loss in transit.

Also companies find it difficult to regulate sales margin of the channel members. This has gone a long way to affect the lack of price uniformity of the products. Hence the channel members took advantage of the brand loyalty of consumers and exploit them. The bureaucracies and excessive costs generated by the activities of middle men which were not checked by the company gave the consumers the opinion that distribution channels are not performing to their full capacity but it must be pointed out that the consumers gave credence to companies that the channels used are not too cumbersome and can be managed if the company choose to do so.

\section{RECOMMENDATIONS}

Considering the above findings and conclusions, the following recommendations have been made.

The channel members should

- Influence several key decisions such as customer service, delivery, and maintain inventory control

- Offer their suppliers real-time access to sales data including information showing how the products are selling by such characteristics as geographic location, type of customer, and product location.

- $\quad$ Count on resellers to provide feedback as to how customers are responding to products. This strategy will improve the profitable growth and market penetration level.

- $\quad$ Streamline their target market to avoid conflict among themselves

- $\quad$ Concentrate on a product line they wish to carry as distributors attempting to handle too many aspects of distribution may end up losing grip of market share.

The Company should establish the following:

- Develop policies that will lead to the clarification of roles and area of jurisdiction of respective channel members.

- $\quad$ Proper registration and recognition of channel members.

- $\quad$ Set realistic and achievable targets for their distributors.

- $\quad$ Place a proper remuneration and compensation package for performing intermediaries.

- $\quad$ Give adequate promotional support

- $\quad$ Improve on delivery terms

- $\quad$ Evaluate channel members regularly to know which to retain or drop

In areas of conflict with the channel members, the company should recognize, acknowledge and manage it in a proper manner that will accrue personal and organizational benefits. An effective manufacturing marketer uses conflict situations as an opportunity for growth and market development for both the organization and the channels involved. When conflict is strategically managed it enhances opportunity for growth. 


\section{AUTHOR INFORMATION}

Dr (Mrs) R.N. Obaji is a lecturer in the Department Of Business Administration, Faculty Of Business Administration, University Of Lagos, Nigeria. She is an alumnus of the University of Calabar, University Of Lagos and Lagos State University all in Nigeria. She has a Bachelor of Science honors in Marketing, Masters of Science in Management, and a Ph.D in Business Administration. She has close to ten years teaching experience in marketing and management, and she has to her credit publications in scholarly journals in the fields of marketing, management and business administration.

\section{REFERENCES}

1. Achumba I.C. (2000), Strategic Marketing Management. Mac - Williams and capital pub. U.S.A.

2. Berman, B. (2004). A guide to developing and managing a well-integrated multi-channel retail strategy. International Journal of Retail \& Distribution Management, 32(2/3), 147.

3. Black, N. (2002). Modeling consumer choice of distribution channels: An illustration from financial services. The International Journal of Bank Marketing, 20(4/5), 161-174.

4. Dent, J (2008).Distribution Channels: Understanding and Managing Channels to Market.

5. Fam, K. (1998). Exploring the relevance of strategic promotion management approach among small independent retailers. International Journal of Retail \& Distribution Management, 26(9), 354.

6. Kotler, PBhilip (2003). Marketing Management, $11^{\text {th }}$ ed Pearson Educational Prentice Hall NY

7. Kotler, Philip and Keller, Kevin (2006). Marketing Management, $12^{\text {th }}$ ed. Pearson Educational Prentice Hall NY

8. Mallen, B. (1996). Selecting channels of distribution: a multi-stage process. International Journal of Physical Distribution \& Logistics Management, 26(5), 5.

9. $\quad$ Nickel, W.G (1998): Marketing Principles. Prentice Hall Inc. U.S.A

10. National Institute of Open Schooling (NIOS); Channels of Distribution Lesson 20 New Delhi, India. (2007) www.nos.org

11. Odugbesan, Olusegun A and Osuagwu, Linus C (1996), Distribution channel management, R.A Publishers Ltd, Ibadan Nigeria.

12. Stern et al, (2006): Marketing Channels, $7^{\text {th }}$ ed Prentice Hall

13. Wilson, E. (2008): A Blueprint for Designing Marketing Channels, (www.chicagostrategy.com) 


\section{NOTES}

